\title{
Pengaruh Penggunaan Media Sosial Terhadap Keputusan Pembelian Kuota Internet Pada Mahasiswa Fakultas Ekonomi dan Bisnis Islam IAIN Palu
}

\author{
Ermawati Ermawati, ${ }^{1}$ Atika Husaini, ${ }^{2,}$ Irham Pakkawaru ${ }^{2}$ \\ ${ }^{1}$ Jurusaan Ekonomi Syariah, Fakultas Ekonomi dan Bisnis Islam, IAIN Palu \\ 2 Jurusaan Ekonomi Syariah, Fakultas Ekonomi dan Bisnis Islam, IAIN Palu \\ ${ }^{3}$ Jurusaan Ekonomi Syariah, Fakultas Ekonomi dan Bisnis Islam, IAIN Palu \\ 34Jurusaan Ekonomi Syariah, Fakultas Ekonomi dan Bisnis Islam, IAIN Palu
}

ABSTRAK

Penelitian ini bertujuan untuk mengetahui pengaruh penggunaan media sosial terhadap keputusan pembelian kuota internet dikalangan mahasiswa Fakultas Ekonomi dan Bisnis Islam IAIN Palu. Penelitian ini menggunakan metode penelitian kuantitatif. Sampel peneilitian ini berjumlah 92 orang mahasiswa Fakultas Ekonomi dan Bisnis Islam. Teknik pengambilan sampel yang digunakan adalah stratified sampling dan proportional sampling. Variabel independen dalam penelitan ini yaitu penggunaan media sosial $(X)$, sedangkan untuk variabel dependennya yaitu pembelian kuota Internet. Teknik pengumpulan data melalui observasi, wawancara, dan angket (kuesioner), teknik analisa data yang digunakan adalah analisis regresi linear berganda yang menggunakan bentuk persamaan $\mathrm{Y}=\mathrm{b}_{0}+\mathrm{b}_{1} \mathrm{X}_{1}+\mathrm{b}_{2} \mathrm{X}_{2}+\mathrm{e}_{\mathrm{i}}$ dengan bantuan program komputer IBM SPSS 21.0. Untuk menganalisis pengaruh variabel independen terhadap veriabel dependen digunakan uji t. Berdasarkan pengolahan data yang telah dilakukan menggunakan SPSS Statistics 21.0 menunjukkan bahwa variabel penggunaan media sosial berpengaruh secara signifikan terhadap keputusan pembelian kuota internet yang dibuktikan dengan nilai $\mathrm{T}_{\text {hitung }} 7.124>\mathrm{T}_{\text {tabel }} 1,661$ dan memiliki nilai signifikan sebesar $0.000<$ 0,05, maka dapat disimpulkan bahwa $\mathrm{H}_{0}$ ditolah dan $\mathrm{H}_{1}$ diterima yang artinya bahwa variabel penggunaan media sosial berpengaruh signifikan terhadap keputusan pembelian.
INFORMASI

ARTIKEL

Katakunci:

Brand switching, variety seeking, fitur produk, handphone, mahasiswa 


\section{Pendahuluan}

Zaman sekarang dengan teknologi yang semakin maju, banyak orang tergantung pada teknologi internet. Hadirnya internet semakin dibutuhkan dalam kehidupan seharihari, baik dalam kegiatan sosialisasi, pendidikan maupun bisnis. Kesempatan ini juga dimanfaatkan vendor smartphone serta tablet murah yang menjamur dan menjadi trend. Hampir semua orang di Indonesia memiliki smartphone, dengan semakin majunya internet dan hadirnya smartphone maka media sosial pun ikut berkembang.

Menurut Asosiasi Penyelenggara Jasa Internet Indonesia (APJII) pada tahun 2017, kurang lebih 143 juta masyarakat Indonesia terhubung dengan internet dan sebanyak 95 persen aktivitas yang mereka lakukan adalah membuka media sosial. Bahkan Indonesia sampai diprediksi akan menjadi negara dengan pengguna sosial media paling aktif dan paling banyak. ${ }^{1}{ }^{2}$

Salah satu alasan yang paling kuat mengapa hal tersebut bisa terjadi adalah karena perangkat-perangkat internet mobile semakin terjangkau harganya bagi masyarakat sehingga memungkinkan pengguna internet dan pengguna media sosial yang lebih luas. ${ }^{3}$

\footnotetext{
${ }^{1}$ Fatimah Kartini Bohang, "Berapa Jumlah Pengguna Internet Indonesia?", diakses dari

https: / / tekno.kompas.com/read/2018/02/ 22/16453177/berapa-jumlah-penggunainternet-indonesia, pada tanggal 1 Juli 2019 pada pukul 20.30.

2 Nurdin, N. (2017). Research in Online Space: The Use of Social Media for Research Setting Jurnal Sistem Informasi (Journal of Information System), 13(1), 6777.

3 Nurdin, N., \& Rusli. (2013). Spiritualising New Media: The Use of Social
}

Berdasarkan hasil riset Wearesosial Hootsuite yang dirilis Januari 2019 pengguna media sosial di Indonesia mencapai 150 juta atau sebesar 56\% dari total populasi. Jumlah tersebut naik $20 \%$ dari survei sebelumnya. Sementara pengguna media sosial mobile (gadget) mencapai 130 juta atau sekitar $48 \%$ dari populasi. ${ }^{4}$

Media sosial yang paling sering digunakan oleh kalangan remaja antara lain : Facebook, Twitter, Path, Youtube, Instagram, LINE, Whatsapp dan lainlain. Masing-masing media sosial tersebut memiliki keunggulan khusus dalam menarik banyak pengguna media sosial yang mereka miliki. ${ }^{5}$

$$
\text { Berdasarkan data yang }
$$
dirangkum Kompas Tekno dari We Are Social, YouTube menempati posisi pertama dengan persentase 43 persen, Facebook, WhatsApp, dan Instagram membuntuti di posisi kedua hingga keempat secara berturut-turut. Sebanyak 41 persen pengguna media sosial Indonesia mengaku sering menggunakan Facebook, 40 persen sering menggunakan WhatsApp, dan 38 persen mengaku sering mengakses Instagram. Sementara pengguna yang mengaku sering mengakses Line

Media for Da'wah Purposes within Indonesian Muslim Scholars. Jurnal Komunikasi islam, 3(1), 1-21.

http://jki.uinsby.ac.id/index.php/jki/articl e/view/55

4Katadata.co.id, 2019, "Berapa Pengguna Media Sosial Indonesia?", https://databoks.katadata.co.id/datapublis h/2019/02/08/berapa-pengguna-mediasosial-indonesia, diakses pada tanggal 14 juli 2019 pukul 22.10.

5Anang Sugeng Cahyono, 2016, "Pengaruh Media Sosial Terhadap Perubahan Sosial Masyarakat di Indonesia", Jurnal Penelitian, h 152.

e-ISSN: $2686-6633$ 
sebanyak 33 persen, dan menempatkannya di posisi kelima.6,7

Direktur Jenderal Informasi dan Komunikasi Publik Kementerian Komunikasi dan Informatika, Rosarita Niken Widiastuti mengatakan "hasil penelitian dari UNESCO menyimpulkan bahwa 4 dari 10 orang Indonesia aktif di media sosial seperti Facebook yang memiliki 3,3 juta pengguna, kemudian WhatsApp dengan jumlah 2,9 juta pengguna dan lain lain". 8 Fakta lainnya, orang Indonesia rata-rata menghabiskan waktu untuk browsing internet dengan berbagai perangkat hingga 8 jam 51 menit. Sementara, rata-rata berkecimpung di medsos dengan berbagai perangkat hingga 3 jam 23 menit. ${ }^{9}$

Menurut hasil riset nasional yang dilakukan oleh Asosiasi Penyedia Jasa

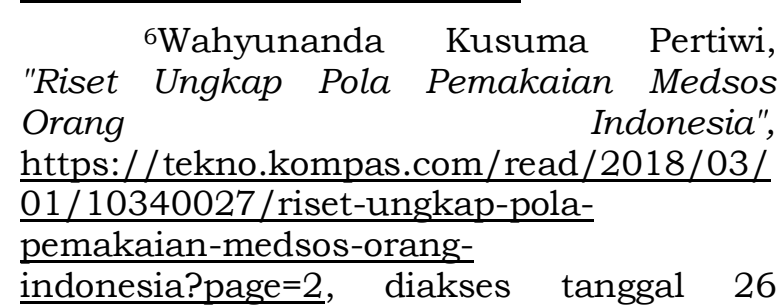
Agustus 2019, pukul 10.47.

7 Nurdin, N., Stockdale, R., \& Scheepers, H. (2013). The Use of Social Media to Gather Qualitative Data: A Case of Government E-Procurement Implementation and Use. 24th Australasian Conference on Information Systems (ACIS)

8KOMINFO, "Angka Penggunaan Media Sosial Orang Indonesia Tinggi, Potensi Konflik juga Amat Besar", https://www.kominfo.go.id/content/detail/ 14136/angka-penggunaan-media-sosialorang-indonesia-tinggi-potensi-konflik-jugaamat-besar/0/sorotan media, diakses tanggal 26 Agustus, pukul 11.14.

${ }^{9}$ Agus Tri Haryanto, "130 Juta Orang Indonesia Tercatat Aktif di Medsos", https://inet.detik.com/cyberlife/d-

3912429/130-juta-orang-indonesiatercatat-aktif-di-medsos, di akses pada tanggal 26 Agustus 2019, pukul 14.26.
Internet Indonesia (APJII) dan Pusat Kajian Universitas Indonesia (UI) tahun 2014, mayoritas pengguna internet di Indonesia berada dalam rentang usia 1825 tahun. Jumlah golongan pengguna muda usia ini bahkan hamper setengah $(49 \%)$ dari total jumlah pengguna internet di Indonesia yang mencapai 88,1 juta di tahun 2014 kemarin. ${ }^{10}$

Hal tersebut memperlihatkan bahwa pengguna internet di Indonesia adalah mereka yang termasuk ke dalam kategori remaja terutama yang lahir di atas tahun 1990-an ketika internet mulai dipergunakan secara luas di masyarakat. Riset tersebut juga membuktikan bahwa remaja merupakan kategori yang mengkonsumsi konten internet dengan intensitas yang cukup besar. Kategori usia pengguna media sosial ini sesuai dengan usia mahasiswa aktif saat ini di Jurusan Ekonomi dan Bisnis Islam.

Media sosial menjadi sarana penting dalam kehidupan sehari-hari dan bisa dibilang media sosial merupakan suatu kebutuhan oleh kalangan akademisi. Perkembangan teknologi internet dan telepon pintar dengan berbagai aplikasi potensial membuat internet menjadi salah satu sumber informasi yang saat ini diperlukan oleh kalangan akademisi dalam mencari sumber informasi, yang berarti juga meningkatkan konsumsi kuota internetnya. Adanya fitur-fitur dari tiap media sosial, membuat penggunanya tak segan menghabiskan isi dompet demi kuota internet.

\section{Nurly Meilinda, 2018, "SOCIAL} MEDIA ON CAMPUS: Studi Peran Media Sosial sebagai Media Penyebaran Informasi Akademik pada Mahasiswa di Program Studi Ilmu Komunikasi FISIP UNSRI", The Journal of Society \& Media, Vol 2 (1), h 56.

e-ISSN: 2686-6633 
Contohnya

mahasiswa

memerlukan internet dalam mencari materi perkuliahan atau sebagai sarana penunjang pembelajaran. Mahasiswa cukup senang menggunakan internet karena lebih efektif dan efisien dibandingkan harus membeli bukubuku yang cukup mahal. Selain untuk mendapatkan informasi, mahasiswa juga mendapatkan kemudahan berkomunikasi dengan teman ataupun dosen tanpa harus membeli pulsa reguler yang memakan banyak biaya. Contohnya aplikasi Whatsapp, dengan aplikasi ini mahasiswa bisa saling mengirim pesan dan juga bisa melakukan panggilan via Whatsapp dengan siapa saja tanpa harus membeli pulsa reguler. Dan salah satu hal yang merupakan pemicu meningkatnya penggunaan media sosial yaitu internet sebagai sarana hiburan. Banyak aplikasi yang bisa dijadikan sarana hiburan, misalnya aplikasi Facebook. Mahasiswa yang tidak mau ketinggalan zaman juga berlomba-lomba mengabadikan momen di akun Facebook mereka, membuat status tentang apa yang sedang terjadi, dan bahkan ada yang bertemu teman lama di Facebook.

Adapun pemanfaatan lainnya dalam penggunaan media sosial di kalangan akdemisi yaitu sebagai wadah transaksi online yang menawarkan barang dan jasa yang kemudian lebih dikenal dengan konsep online shop. Tidak sedikit mahasiswa/mahasiswi yang berbelanja di online shop karena lebih mudah. Mereka tahu bahwa hanya dengan melihat gambar di sosial media mereka bisa memilih dan membeli barang yang mereka mau tanpa harus keluar rumah.

\section{Kerangka Teori}

\subsection{Media Sosial}

Media sosial adalah medium di internet yang memungkinkan pengguna merepresentasikan dirinya maupun berinteraksi, bekerja sama, berbagi, berkomunikasi dengan pengguna lain, dan membentuk ikatan sosial secara virtual. ${ }^{11}, 12,13$

Menurut Lometti, Reeves, Bybee penggunaan media oleh individu dapat dilihat dari tiga hal, yaitu: ${ }^{14}$

a. Jumlah waktu, hal ini berkaitan dengan frekuensi, intensitas, dan durasi yang digunakan dalam mengakses situs;

b. Isi media, yaitu memilih media dan cara yang tepat agar pesan yang ingin disampaikan dapat dikomunikasikan dengan baik.

c. Hubungan media dengan individu dalam penelitian ini adalah keterkaitan pengguna dengan media sosial.

1. Fungsi Media Sosial

11 Nurdin, N. (2012). Penggunaan Media Sosial Online dalam Berdakwah: Kemungkinan Adopsi dan Strategi Pemanfaatannya. Al-Mishbah: Jurnal Ilmu Dakwah dan Komunikasi, 8(1), 177-198.

12 Nurdin, N. (2017). Research in Online Space: The Use of Social Media for Research Setting Jurnal Sistem Informasi (Journal of Information System), 13(1), 6777.

13 Nurdin, N. (2017b). To Research Online or Not to Research Online: Using Internet-Based Research in Islamic Studies Context. Indonesian Journal of Islam and Muslim Societies, 7(1), 31-54.

${ }^{14}$ Thea Rahmani, 2016, Penggunaan Media Sosial Sebagai Penguasaan DasarDasar Fotografi Ponsel, Universitas Islam Negeri Sunan Kalijaga Yogyakarta, h 22.

e-ISSN: 2686-6633 
McQuail berpendapat bahwa fungsi utama media bagi masyaraka adalah: ${ }^{15}$

a. Informasi

1) Inovasi, adaptasi, dan kemajuan.

b. Korelasi

2) Menjelaskan, menafsirkan, mengomentari makna peristiwa dan informasi.

3) Menunjang otoritas dan normanorma yang mapan.

4) Mengkoordinasi beberapa kegiatan.

5) Membentuk kesepakatan.

c. Kesinambungan

1) Mengekspresikan budaya dominan dan mengakui keberadaan kebudayaan. khusus (subculture) serta perkembangan budaya baru.

2) Meningkatkan dan melestarikan nilainilai.

d. Hiburan

1) Menyediakan hiburan, pengalihan perhatian, dan sarana relaksasi.

2) Meredakan ketegangan sosial.

e. Mobilisasi

1) Mengkampanyekan tujuan masyarakat dalam bidang politik, perang, pembangunan ekonomi, pekerjaan, dan kadang kala juga dalam bidang agama.

\section{Jenis-Jenis Media Sosial}

a. Aplikasi Media Sosial Berbagi Video (Video Sharing)

Aplikasi berbagi video tentu sangat efektif untuk menyebarkan beragam program pemerintah. Program tersebut dapat berupa kunjungan atau pertemuan di lapangan, keterangan pemerintah, diskusi publik tentang suatu kebijakan, serta berbagai usaha

\footnotetext{
${ }^{15}$ Denis McQuail, Teori Komunikasi Massa Suatu Pengantar, (Jakarta: Erlangga, 1992), h 71.
}

dan perjuangan pemerintah melaksanakan perdagangan. ${ }^{16}, 17$ program-program Sebelum melakukan penyebaran, suatu video memerlukan tahap verifikasi sesuai standar berlaku. Sebaliknya, pemerintah juga perlu memeriksa, membina serta mengawasi video yang tersebar di masyarakat yang terkait dengan program perdagangan pemerintah. Sejauh ini, dari beragam aplikasi video sharing yang beredar setidaknya ada tiga program yang perlu diperhatikan, terkait dengan jumlah user dan komunitas yang telah diciptakan oleh mereka yakni YouTube, Vimeo dan Daily Motion.

b. Aplikasi Media Sosial Blog \& Mikroblog

Blogs and Microblogs, yaitu aplikasi yang dapat membantu penggunanya untuk menulis secara runut dan rinci mengenai berita, opini, pengalaman, ataupun kegiatan seharihari, baik dalam bentuk teks, gambar, video, ataupun gabungan dari ketiganya. Kedua aplikasi ini mempunyai peran yang sangat penting baik dalam penyampaian informasi maupun pemasaran produk. Melalui kedua aplikasi tersebut, pihak pengguna

${ }^{16}$ Nurdin, N., \& Rusli. (2012). Social Media Adoption and Use Within Indonesian Muslim Scholars: A Possible Adoption and Use for "Dakwah" Purposes Annual Conference on Islamic Studies (ACIS) 12 November 05-08 2012, Surabaya Indonesia.

${ }^{17}$ Nurdin, N., \& Rusli. (2013).

Spiritualising New Media: The Use of Social Media for Da'wah Purposes within Indonesian Muslim Scholars. Jurnal Komunikasi islam, 3(1), 121.

http://jki.uinsby.ac.id/index.php/jki/article/vi ew $/ 55$ 
dengan leluasa dapat mengiring opini masyarakat atau pengguna internet untuk lebih dekat dengan mereka tanpa harus bersusah-susah menyampaikan informasi secara tatap muka. ${ }^{18}$

c. Aplikasi Media Sosial Berbagi Jaringan Sosial

Jejaring Sosial, yaitu merupakan situs yang dapat membantu seseorang atau pengguna internet membuat sebuah profil dan menghubungkannya dengan pengguna lain. Situs jejaring sosial memungkinkan penggunanya mengunggah hal-hal yang sifatnya pribadi seperti foto, video, koleksi tulisan, dan saling berhubungan secara pribadi dengan pengguna lainnya melalui private pesan yang hanya bisa diakses dan diatur pemilik akun tersebut. Situs jejaring sosial sangat berperan dalam hal membangun dan membentuk brand image, karena sifatnya yang interaktif sehingga pengguna dapat dengan mudah mengirim dan menerima informasi, bahkan dapat digunakan sebagai media komunikasi dan klarifikasi yang nyaman antara pemilik produk dengan konsumenya. ${ }^{19}$

Setidaknya ada tiga aplikasi berbagi jaringan sosial yang menonjol dan banyak penggunanya di Indonesia, khususnya untuk tipe ini. Yakni Facebook, Google Plus, serta Path. Masing-masing memang memiliki kelebihan dan kekurangan tersendiri. . d. Aplikasi Berbagi Jaringan Profesional

Para pengguna aplikasi berbagi jaringan professional umumnya terdiri atas kalangan akademi, mahasiswa para

${ }^{18}$ Kaplan \& Haenlin, 2010, "Users of the world, unite! The challenges and opportunities of social media", Business Horizons 53(1), h 60.

${ }^{19}$ Kaplan \& Haenlin, h 60-61. peneliti, pegawai pemerintah dan pengamat. Dengan kata lain, mereka adalah kalangan kelas menengah Indonesiayang sangat berpengaruh dalam pembentukkan opini masyarakat. Sebab itu, jenis aplikasi ini sangat cocok untuk mempopulerkan dan menyebarkan misi perdagangan yang banyak memerlukan telaah materi serta ha-hal yang memerlukan perincian data. Juga efektif untuk menyebarkan dan mensosialisasikan perundang-undangan atau peraturan-peraturan lainnya. Sejumlah aplikasi jaringan profesional yang cukup populer di Indonesia antara lain LinkedIn, Scribd dan Slideshare. ${ }^{20}$

e. Aplikasi Berbagi Foto

Aplikasi jaringan berbagi foto sangat populer bagi masyarakat Indonesia. Sesuai karakternya, aplikasi ini lebih banyak menyebarkan materi komunikasi soslia yang lebih santai, tidak serius, kadang-kadang banyak mengandung unsur-unsur aneh, eksotik, lucu, bahkan menyeramkan. Sebab itulah, penyebaran program pemerintah juga efektif dilakukan lewat aplikasi ini. Tentu saja, materi yang disebarkan juga harus menyeuaikan karakter aplikasi ini. Materi itu dapat berupa kunjungan misi perdagangan ke daerah yang unik, eksotik, pasar atau komunitas perdagangan tertentu. Beberapa aplikasi yang cukup populer di Indonesia antara lain Pinterest, Picasa, Flickr, dan Instagram.

\subsection{Keputusan Pembelian}

Keputusan konsumen adalah suatu tindakan konsumen untuk membentuk referensi diantara produk-

${ }^{20}$ Tim Pusat Humas, 75.

e-ISSN: $2686-6633$ 
produk dalam kelompok pillihan dan membeli produk yang paling disukai. ${ }^{21}$

Menurut Boyd Walker pengambilan keputusan pembelian merupakan sebuah pendekatan penyelesaian masalah pada kegiatan manusia membeli suatu produk guna memenuhi keinginan dan kebutuhan. ${ }^{22}$

Dari definisi-definisi tersebut dapat ditarik kesimpulan bahwa pengambilan keputusan adalah proses bagaimana menetapkan suatu keputusan yang terbaik, logis, rasional, dan ideal berdasarkan fakta, data dan informasi dari sebuah alternatif untuk mencapai sasaran-sasaran yang ditetapkan dengan resiko yang kecil, efektif, dan efisien .

\subsection{Tahapan Keputusan Pembelian}

Seseorang apabila membeli suatu produk, tentunya bukan suatu hal yang kebetulan. Hal ini melalui proses yang panjang dan mempunyai beberapa tahapan. Antara tahap satu dengan yang lain saling berkaitan dan berpengaruh.

Model tahapan proses membeli digunakan apabila, produk yang dibeli oleh konsumen adalah baru atau suatu barang yang memerlukan pertimbangan tinggi dan lama dalam pembeliannya, misalnya, mobil, rumah, komputer. Seseorang akan membeli rumah tertentu apabila sudah ada pertimbangan yang sudah matang dan persiapan yang baik pula. Tetapi seperti barang keperluan sehari-hari misalnya sabun mandi, pasta gigi, ini tidak perlu melalui lima tahap

${ }^{21}$ Philip Khoter, Manajemen Pemasaran Prenhallindo, edisi 9, (Jakarta, 2009), h 204.

${ }^{22}$ Boyd Walker, Manajemen Pemasaran, Jiid I, (Jakarta: Erlangga, 1997), h 123. ini, bahkan apabila merek barang sudanh menjadi barang kebiasaan. ${ }^{23}$

a. Pengenalan Masalah

Prosee pembelian dimulai ketika pembeli menyadari suatu masalah atau kebutuhan yang dipicu oleh rangsangan internal atau eksternal. Dengan rangsangan internal, salah satu dari kebutuhan seseorang normal-rasa lapar, seks-naik maksimum dan menjadi dorongan; atau kebutuhan bisa timbul akibat rangsangan eksternal. Seseorang mungkin mengagumi mobil baru tetangga atau melihat iklan di televisi untuk liburan ke hawai, yang memicu pemikiran tentang kemungkinan melakukan pembelian. ${ }^{24}$

Pemesaran

harus mengidentifikasi keadaan yang memicu kebutuhan tertentu dengan mengumpulkan informasi dari sejumlah konsumen. Lalu merekan dapat mengembangkan strategi pemasaran yang memicu minat konsumen. Terutama untuk pembelian fleksibel seperti barang-barang mewah, paket liburan, dan pilihan liburan, pemasar mungkin harus meningkatkan motivasi konsumen sehingga pembelian potensial mendapat pertimbangan serius.

b. Pencarian Inforasi

Konsumen yang terangsang ebutuhannya akan terdorong untuk mencari informasi yang lebih banyak. Kita dapat membaginya ke dalam dua level rangsangan. Situasi pencarian informasi yang lebih ringan dinamakan pungutan perhatian. Pada level ini

${ }^{23}$ Daryanto dan Ismanto setyabudi, Konsumen dan Pelayanan Prima (Yogyakarta: Gava media, 2014), h 84-85.

${ }^{24}$ Philip Khotler dan Kevin Lene keller, Manajemen Pemasaran, Edisi 12, Jilid I, (Erlangga, 2008), h 235. 
orang hanya sekedar lebih peka terhadap informasi produk. Pada level selanjutnya, orang itu akan mulai aktif mencari informasi: mencari bahan bacaan, menelpon teman, dan mengunjungi toko untuk mempelajari produk tertentu.

c. Evaluasi Alternatif

Terdapat beberapa proses evaluasi keputusan dan model-model terbaru yang memandang proses evaluasi konsumen membentuk penilaian atas produk dengan sangat sadar dan rasional. ${ }^{25}$

Beberapa konsep dasar akan membantu kita memahami proses evaluasi konsumen. Pertama, konsumen berusaha memenuhi kebutuhan. Kedua, konsumen mencari manfaat tertentu dari solusi produk. Ketiga, konsumen memandang masing masing produk sebagai atribut dengan kemampuan yang berbeda-beda dalam memberikan manfaat yang digunakan untuk memuaskan kebutuhan itu

d. Keputusan Pembelian

Dalam tahap evealuasi, konsumen membentuk preferensi atas merek-merek yang ada di dalam kumpulan pilihan. Konsumen juga dapat membentuk niatdalam membeli produk yang paling disukai. Dalam melaksanakan maksud pembelian, konsumen bisa mengambil lima subkeputusan: merek, dealer, kuantitas, waktu, dan metode pembayaran. Dalam pembelian produk sehari-hari, keputusannya lebih kecil dan kebebasannya juga lebih kecil.

e. Perilaku Pasca Pembelian

Setelah melakukan pembelian, konsumen mungkin mengalami

${ }^{25}$ Khotler dan Keller, h 184. ketidaksesuain karenamemerhatikan fitur-fitur tertentu yang mengganggu atau mendengar hal-hal yang menyenangkan tentang merek-merek lain dan akan selalu siaga terhadap informasi yang endukung keputusannya. Komunikasi pemasaran harus memasok keyakinan dan evaluasi yang mengukuhkan pilihan konsumen dan membantu dia merasa nyaman dengan merek.

\subsection{Perilaku Konsumen}

Perilaku konsumen adalah tindakan yang langsung terlibat dalam mendapatkan , mengonsumsi, dan menghabiskan produk atau jasa, termasuk proses keputusan yang mendahuli dan menyusuli tindakan ini. Keputusan pembelian dari pembeli sangat dipengaruhi oleh faktor kebudayaan, sosial, pribadi, dan psikologi dari pembeli. Sebaian besar adalah faktor-faktor yang tidak dapat dikendalikan oleh pemasar, tetapi harus benar-benar diperhitungkan. ${ }^{26}$

Perilaku konsumen merupakan bagian dari manajemen pemasaran yang berhubungan dengan manusia sebagai pasar sasaran. Pelanggan merupakan komponen lingkungan yang mampu mempengaruhi pencapaian tujuan pemasaran. Prinsip pemasaran mengatakan bahwa pencapaian tujuan organisasi tergantung pada seberapa mampu organisasi tersebut memahami kebutuhan dan keinginan pelanggan dan memenuhinya secara lebih efifien dan efektif dibanding pesaing. Intinya, apabila ingin memberikan nilai yang terbaik bagi para pelanggan, sebuah

${ }^{26}$ Setiadi.Nugroho.J, Perilaku Konsumen, (Jakarta: Prenada Media Group, 2010), h 10.

e-ISSN: 2686-6633 
perusahaan harus memiliki informasi mengenai siapa pelanggannya dan bagaimana karakteristik dan perilaku mereka. ${ }^{27}$

Pemahaman ekspetasi konsumen dapat mempunyai dampak yang penting pada strategi harga. Secara umum, harga yang lebih tinggi, kurang mempunyai kemungkinan untuk dibeli oleh konsumen (teori ekonomi mikro). Bagaimanapun dalam beberapa kondisi, konsumen mempunyai ekspektasi atas hubungan harga dan kualitas. Dalam rentang harga tertentu untuk suatu produk, konsumen mungkin mempunyai ekspektasi bahwa harga yang lebih mencerminkan kualitas yang lebih baik.

Konsumen tentunya ingin mendapatkan produk dan jasa serta pemuas kebutuhan yang dapat memenuhi kebutuhan hidup mereka. Banyak konsumen di Indonesia yang menjadi masyarakat konsumsi tinggi dalam membeli barang/produk bahkan sampai ada yang membeli suatu produk sampai ke luar negeri hanya untuk mendapatkan produk tersebut, itulah sebagian besar masyarakat yang mempunyai dana lebih dan berperilaku sedemikian rupa, tetapi ada juga masyarakat yang biasa-biasa saja, mereka membeli produk cukup di dalam negeri, membeli barang disesuaikan dengan kebutuhan hidup dari dana yang dimiliki dan juga mencari produk yang walaupun harganya murah tetapi dapat mencukupi kebutuhan mereka.

\subsection{Teori Konsumsi}

${ }^{27}$ Bilson Simamora, Panduan Riset Perilaku Konsumen, (Jakarta: PT Gramedia Pustaka Utama, 2000), h 25. a. Teori konsumsi klasik

1) Karl Marx

Kontribusi Marx (dalam Sedjatmiko, 2008:20) di dalam teori konsumsi adalah melalui analisis mengenai apa yang membentuk dan menyusun kebutuhan-kebutuhan manusia, dan bagaimanakah kebutuhankebutuhan itu dapat bertemu di dalam aplikasi proses produksi. Objek kerja (produk) berperan krusial dalam mengontruksi keadaan hidup manusia secara personal. Melalui konteks pemahaman ini, komoditas dipahami Marx sebagai proses produksi.

Marx mendefinisikan alat-alat produksi (means of production) sebagai komoditas yang memiliki suatu bentuk dimana komoditas memasuki konsumsi produktif. Sedangkan alat-alat konsumsi (means of consumtion) didefinisikan sebagai komoditas yang memiliki suatu bentuk dimana konsumsi itu memasuki konsumsi individual dari kelas kapitalis dan pekerja. Konsekuensi dari pembagian tersebut adalah pengklasifikasian jenis konsumsi, yaitu konsumsi subsistensi dan konsumsi mewah. Konsumsi subsistensi adalah alat-alat konsumsi yang diperlukan (necessary means of consumption) atau yang memasuki kelas pekerja. Bahan kebutuhan pokok (sandang, pangan, dan papan) dipandang sebagai konsumsi subsistensi. Sedangkan konsumsi mewah adalah alat-alat konsumsi mewah (luxury means of consumption), yang hanya memasuki konsumsi kelas kapitalis, yang dapat dipertukarkan hanya untuk pengeluaran dari nilai surplus yang tidak diberikan kepada pekerja. ${ }^{28}$

${ }^{28}$ Damsar, h 114-115.

e-ISSN: $2686-6633$ 
2) Max Weber

Teori Weber amat di pengaruhi oleh semangat kalvinisme yang membangkitkan etos kerja dan sikap saleh terhadap karya. Hal ini kemudian mendorong pekerja untuk tidak mengonsumsi kelebihan yang dimiliki, melainkan menginvestasikannya. Dari sudut pandang ini, kapitalisme tampak jelas oleh karena adanya etos kerja yang mengutamakan penanaman modal kembali daripada mengonsumsi. Weber melihat bahwa kapitalisme dicirikan dengan pengejaran keuntungan melalui cara pengembangan kapital secara rasional dan berkelanjutan, yaitu pembaharuan keuntungan secara konstan. ${ }^{29}$

Pandangan Weber difokuskan pada argumen bahwa revolusi industri telah menyebabkan pergolakan dunia besar-besaran dengan produk pabrik yang dihasilkan. Diskusi mengenai hakikat "semangat kapitalisme" yang pada dasarnya irasional dan semakin bertambahnya kehausan akan uang, yang diikuti penolakan aktual pada kenikmatan hidup spontan, menghasilkan generasi yang mengalami konsumsi sebagai hal yang dapat dinikmati dan menyenangkan dimasa sekarang.

3) George Simmel

Simmel melihat uang, dan secara khusus pertukaran sebagai pusat pengalaman modernitas. Hal ini menarik, dalam arti membangkitkan kemungkinan bahwa konsumsi lebih daripada sekedar minat insidental, dan secara aktual memiliki beberapa peran dalam menstrukturisasi pengalaman modernitas seseorang. Munculnya kota

\footnotetext{
${ }^{29}$ Sujatmiko, 21-22.
}

memiliki implikasi signifikan di dalam pembentukan hidup sosial, dan selanjutnya berimplikasi juga pada meningkatnya konsumsi. Pembangunan kota dinilai mampu memenuhi, memuaskan kebutuhan-kebutuhan sosial, dan psikologis penduduknya. Disinilah peran konsumsi. Sampai disni, Simmel ternyata mengetahui peran formatif bahwa konsumerisme mengkontruksi hidup sehari-hari pada akhir abad dua puluh ini. ${ }^{30}$

b. Era kebangkitan sosiologi konsumsi

Menurut Pieree Bourdieu, manusia termotivasi oleh kebutuhan memproduksi sebuah acuan kolektif yang didasarkan pada demarkasi kelas. Disini apa yang dimaksud modal budaya menjadi krusial, dalam arti bahwa perbedaan kelas-kelas terkualifikasi secara edukatif untuk memperoleh keuntungan dari aspekaspek yang berbeda dengan model simbolik. Maka, kelas yang dominan akan menunjukkan superioritas melalui akses kepada budaya dan konsumsi yang tinggi. Dari sini implikasi yang dapat muncul adalah bahwa konsumsi menyediakan sejumlah sumber-sumber daya yang menopang kehidupan seharihari konsumen. ${ }^{31}$

Tentu saja akses kepada sumber daya alam ini bergantung pada akses terhadap sumber-sumber ekonomi. Dalam hal ini konsumsi tidak dianalisis sebagai bentuk pemusaan kebutuhankebutuhan yang berakar secara biologis. Lebih jauh, konsumsi sebagaimana ditekankan Bourdieu, yang meliputi tanda, simbol, ide,dan nilai digunakan sebagai cara memisahkan satu kelompok

\footnotetext{
${ }^{30}$ Sujatmiko, h 23-24.

${ }^{31}$ Sujatmiko, h 35.
}

e-ISSN: 2686-6633 
sosial dengan kelompok sosial lainnya. Dengan demikian, Bourdieu tidak melihat kebiasaan-kebiasaan konsumsi sebagai suatu produk dari struktur sosial, namun terlebih sebagai interaksi antar individu dengan masyarakat.

Pandangan Bourdieu telah membangun sebuah konsep "habitus" , yakni modal pengetahuan atau budaya sehari-hari yang merefleksikan pengalaman rutin dengan tingkah laku yang sesuai dengan budaya-budaya partikular. Habitus juga berperan penting dalam mengkontruksi gaya hidup, dimana produk sistematisnya menjadi sistem-sistem penanda kualifikasi sosial. ${ }^{32}$

f. Konsumsi dan postmodernisme

1) Mike Featherstone

Menurut Featherstone, konsumsi secara alami telah memberikan identitas yang tidak selalu terbatas bagi kaum muda dan kaum kaya, melainkan secara potensial berdampak pada kehidupan setiap orang. Di dalam dunia postmodern, segala sesuatu adalah mungkin. Maksudnya, seseorang dapat menjadi siapapun yang mereka inginkan sejauh mereka telah siap untuk mengkonsumsi. ${ }^{33}$

Pada relasi antara konsumsi dan postmodernisme, Featherstone juga melihat adanya transformasi realitas terkait dengan imaji dan fragmentasi waktu, namun secara lebih partikular, dimana pengalaman seni dan estetika menjadi paradigma utama bagi pengetahuan, pengalaman, dan pemaknaan hidup.

2) Jean Baudrillard

\footnotetext{
${ }^{32}$ Sujatmiko, h 35.

33Sujatmiko, h 36.
}

Masyarakat konsumsi adalah konsep kunci dalam pemikiran Baudrillard untuk menunjukkan gejala konsumerisme yang sangat luar biasa dan telah menjadi bagian dari gaya hidup manusia modern. Objek konsumsi tidak hanya berupa barang, namun lebih dari itu. Baudrillard mengawali diskusi tentang masyarakat konsumsi dengan melihat gejala globalisasi yang tengah marak diseluruh dunia. Perkembangan globalisasi diawali oleh paham kapitalisme yang memanfaatkan momen globalisasi untuk memperluas pangsa pasar mereka. ${ }^{34}$

\subsection{Perilaku Konsumen dalam Islam}

Dalam Islam perilaku manusia telah diatur dalam agama Islam. Demikian pula dalam masalah konsumsi, Islam mengatur bagaimana manusia bisa melakukan kegiatankegiatan konsumsi yang akan membawa manusia yang berguna bagi kemaslahatan hidupnya. Dalam alQurean dan al-Hadits juga mengatur tentang jalan hidup manusia, agar manusia dijauhkan dari sifat hina karena perilaku konsumsi manusia.

Jadi, perilaku konsumen muslim merupakan suatu aktivitas manusia yang berkaitan dengan aktivitas membeli dan menggunakan produk barang dan jasa, dengan memperhatikan kaidah ajaran Islam, dan berguna bagi kemaslahatan umat. Yang demikian itu, dalam mengkonsumsi, menyimpan, mengelola, dan memebili barang atau jasa dengan cara yang halal lagi baik, merupakan hal-hal yang sangat

${ }^{34}$ Nanang Martono, Sosiologi Perubahan Sosial: Perspektif Klasik, Modern, Posmodern dan Poskolonial, (Jakarta: Rajagrafindo Persada, 2012), h 130. 
diagungkan pembalasannya, dan dikabulkan do'anya. ${ }^{35,36}$

Allah Swt tentu melarang kita berbuat israf (berlebih-lebihan) dalam dalam membelanjakan harta kekayaan. Orang yang suka menghamburhamburkan harta kekayaan, baik di jalan yang dibenarkan oleh agama maupun yang tidak dibenarkan dalam agama. Orang yang seperti ini tidak memikirkan akan susahnya dari mana harta yang ia dapatkan. Dalam hal ini Al-quran mencela orang-orang yang suka menghambur-hamburkan hartanya atau disebut dengan pemborosan.

Sebagaimana firman Allah Swt, di dalam surat al israa ayat 26-27 yang terjemahannya sebagai berikut:

Dan berikanlah kepada keuargakeluarga yang dekat akan haknya, kepada orang miskin dan orang yang dalam perjalanan dan janganlah kamu menghambur-hamburkan (hartamu) secara boros, Sesungguhnya pemboros-pemboros itu adalah saudara-saudara syaitan dan syaitan itu adalah sangat ingkar kepada Tuhannya. ${ }^{37}$

Setiap orang mukmin berusaha mencari kenikmatan dengan cara mematuhi perintahnya dan memuaskan diri sendiri dengan barang-barang dan anugerah yang diciptakan Allah untuk kemaslahatan umat. Konsumsi secara berlebihan merupakan ciri seorang yang tidak mengenal Tuhan, mereka dikutuk

${ }^{35}$ Heri Sudarsono, Konsep Ekonomi Islam, (Yogyakarta: Ekonosia, 2002), h 167.

${ }^{36}$ Nurdin, N., Novia, N., Rahman, A., \& Suhada, R. (2019). Potensi Industri Produk Makanan Halal Di Kota Palu. Jurnal Ilmu Ekonomi dan Bisnis Islam, 1(1), 1-12.

37Departemen Agama Republik Indonesia, Terjemah \& Tafsir Al-Qur'an, (Jakarta: Fa, Sumatra, 1978), h 532. dalam Islam dan disebut sebagai perilaku israf (pemborosan) atau tabzir (menghambur-hamburkan harta tanpa guna).

Dalam ekonomi Islam, dikenal dengan adanya saluran penyeimbang yang disebut dengan konsumsi sosial. Al-Qurean mengajarkan kepada umat Islam agar dapat menyalurkan sebagian hartanya dalam bentuk zakat, sedekah dan infaq. Kebutuhan sosial akan dimanfaatkan fakir dan miskin dalam bentuk pendayagunan konsumtif dan produktif. Dalam pendayaan konsumtif uang atau harta digunakan untuk memenuhi kebutuhan pokok secara langsung. Sedangkan dalam pendayaan produktif uang atau hartanya digunakan untuk membuka lapangan pekerjaan sehingga fakir dan miskin mempunyai pekerjaan. ${ }^{38}$

\section{Metode Penelitian}

Pendekatan yang digunakan dalam penelitian ini adalah pendekatan kuantitaif, karena penelitian ini terfokus untuk mengetahui pengaruh variabel penggunaan media sosial terhadap pembelian kuota internet.

Penelitian ini dilakukan di Institut Agama Islam Negeri (IAIN) Palu yang bertempat di Jl. Diponegoro No.23, Kecamatan Palu Barat, Kota Palu, Sulawesi Tengah. Lokasi ini di ambil oleh peneliti dengan pertimbangan bahwa lokasi tersebut mudah untuk diakses dan dijangkau dan juga mahasiswa merupakan objek dalam penelitian ini. Peneliti memberikan questioner kepada 92 respondent mahasiswa fakultas Ekonomi dan Bisnis

${ }^{38}$ Yusuf Qardhawi, Norma dan Etika Ekonomi Islam, (Jakarta: Gema Insani Press, 1997), h 51.

e-ISSN: $2686-6633$ 
Islam IAIN Palu. Quesioner menggunakan lima skala likert .

Teknik analisis data yang digunakan dalam penelitian ini adalah analisis kuantitaif, yaitu proses analisis terhadap data-data yang berbentuk angka dengan cara perhitungan secara statistik untuk mengukur kualitas produk dan desain terhadap keputusan pembelian motor. Analisa data dilakukan melalui tahap uni validitas, reabilitas, uji regresi berganda, dan uji asumsi klasik. Untuk oembuktian hipotesis penulis menggunakan uji $\mathrm{f}$ dan uji t.

\section{Hasil Dan Pembahasan}

\subsection{Deskripsi Kuesioner dan Sampel Penelitian}

Penelitian ini dilakukan pada Mahasiswa Fakultas Ekonomi dan Bisnis Islam Institut Agama Islam Negeri (IAIN) Palu, Jl. Diponegoro No. 23 Palu. Data penelitian menggunakan instrumen kuesioner yang dibagikan kepada Mahasiswa Fakultas Ekonomi dan Bisnis Islam yang terdiri dari 2 Jurusan sebagai sampel penelitian. Kuesioner disebarkan oleh peneliti kepada sampel yang diteliti dengan perincian sebagai berikut:

Tabel 1

Deskripsi Kuesioner

\begin{tabular}{|c|c|c|c|c|}
\hline $\begin{array}{c}\text { Jumlah } \\
\text { Sampel }\end{array}$ & $\begin{array}{c}\text { Kuesioner } \\
\text { Disebar }\end{array}$ & $\begin{array}{c}\text { Kuesioner } \\
\text { Kembali }\end{array}$ & $\begin{array}{c}\text { Kuesioner } \\
\text { Diolah }\end{array}$ & Presentase \\
\hline 92 & 92 & 92 & 92 & $100 \%$ \\
\hline
\end{tabular}

Dalam tabel dijelaskan bahwa jumlah sampel yang digunakan dalam penelitian ini adalah 92 orang mahasiswa Fakultas Ekonomi dan Bisnis Islam IAIN Palu. Data responden dalam penelitian ini dijelaskan dalam tabel sebagai berikut:

Tabel. 2 Jenis Kelamin Responden

\begin{tabular}{|c|c|c|c|c|c|}
\hline & & Frequency & Percent & $\begin{array}{c}\text { Valid } \\
\text { Percent }\end{array}$ & $\begin{array}{c}\text { Cumulative } \\
\text { Percent }\end{array}$ \\
\hline \multirow[t]{3}{*}{ Valid } & Laki-Laki & 36 & 39.1 & 39.1 & 39.1 \\
\hline & $\begin{array}{l}\text { Perempua } \\
\mathrm{n}\end{array}$ & 56 & 60.9 & 60.9 & 100.0 \\
\hline & Total & 92 & 100.0 & 100.0 & \\
\hline
\end{tabular}

Pada tabel di atas menunjukkan bahwa dari 92 orang jumlah sampel dalam penelitian ini yang berjenis kelamin laki-laki berjumlah 36 orang $(39,1 \%)$ dan yang berjenis kelamin perempuan berjumlah 56 orang $(60,9 \%)$. Sehingga sampel dalam penelitian ini sebagian besar berjenis kelamin perempuan.

Tabel. 3

\begin{tabular}{|l|r|r|r|r|r|}
\hline \multicolumn{7}{|c|}{ Tahun Angkatan Responden } \\
\hline & & Frequency & Percent & Valid Percent & $\begin{array}{c}\text { Cumulative } \\
\text { Percent }\end{array}$ \\
\hline Valid 2016 & 26 & 28.3 & 28.3 & 28.3 \\
& 2017 & 30 & 32.6 & 32.6 & 60.9 \\
& 2018 & 36 & 39.1 & 39.1 & 100.0 \\
& Total & 92 & 100.0 & 100.0 & \\
\hline
\end{tabular}

Pada tabel di atas menunjukkan bahwa jumlah responden dari setiap angkatan, dimana responden terbanyak berasal dari angkatan 2018 atau semester empat yaitu sebnyak $36 \quad(39,1 \%)$ kemudian dari angkatan 2017 atau semester enam yaitu sebanyak 30 responden $(32,6 \%)$, dan yang terakhir responden angkatan 2016 atau semester delapan yaitu sebanyak 26 responden $(28,3 \%)$.

Terkait dengan jumlah media sosial yang digunakan dapat dilihat pada tabel4 berikut ini. 
Jurnal Ilmu Ekonomi dan Bisnis Islam - JIEBI

Vol.1 No. 1 Tahun 2019

Tabel 4

\begin{tabular}{|c|c|c|c|c|c|}
\hline \multicolumn{6}{|c|}{ Jumlah Media Sosial yang digunakan } \\
\hline & & $\begin{array}{l}\text { Frequ- } \\
\text { ency }\end{array}$ & Percent & $\begin{array}{c}\text { Valid } \\
\text { Percent }\end{array}$ & $\begin{array}{c}\text { Cumulative } \\
\text { Percent }\end{array}$ \\
\hline \multirow[t]{6}{*}{ Valid } & 2 & 1 & 1.1 & 1.1 & 1.1 \\
\hline & 3 & 51 & 55.4 & 55.4 & 56.5 \\
\hline & 4 & 34 & 37.0 & 37.0 & 93.5 \\
\hline & 5 & 5 & 5.4 & 5.4 & 98.9 \\
\hline & 6 & 1 & 1.1 & 1.1 & 100.0 \\
\hline & Total & 92 & 100.0 & 100.0 & \\
\hline
\end{tabular}

Pada tabel di atas menujukkan jumlah media sosial yang di gunakan, dimana responden yang menggunakan dua media sosial berjumlah 1 responden $(1,1 \%)$, yang menggunakan 3 media sosial berjumlah 51 responden $(55,4 \%)$, yang menggunakan 4 media sosial berjumlah 34 responden (37\%), kemudian yang menggunakan 5 media sosial berjumlah 5 responden $(5,4 \%)$, serta yang menggunakan 6 media sosial berjumlah 1 responden $(1,1 \%)$.

Tabel 5

\begin{tabular}{|l|l|r|r|r|r|}
\hline \multicolumn{7}{|c|}{ Tabel 5} \\
\hline & & $\begin{array}{c}\text { Frequ- } \\
\text { ency }\end{array}$ & Percent & $\begin{array}{c}\text { Valid } \\
\text { Percent }\end{array}$ & $\begin{array}{c}\text { Cumulative } \\
\text { Percent }\end{array}$ \\
\hline Valid & $5,000-50,000$ & 14 & 15.2 & 15.2 & 15.2 \\
\cline { 2 - 6 } & $51,000-100,000$ & 72 & 78.3 & 78.3 & 93.5 \\
\hline $101,000-150,000$ & 5 & 5.4 & 5.4 & 98.9 \\
\hline 150,000 & 1 & 1.1 & 1.1 & 100.0 \\
\hline & Total & 92 & 100.0 & 100.0 & \\
\hline
\end{tabular}

Pada tabel di atas menujukkan uang yang dikeluarkan responden untuk membeli kuota internet, dimana yang mengeluarkan uang kisaran 5,00050,000 berjumlah 14 responden $(15,2 \%)$, yang mengeluarkan uang kisaran 51,000-100,000 berjumlah 72 responden $(78,3 \%)$, dan yang mengeluarkan uang kisaran 101,000-150,000 berjumlah 5 responden $(5,4 \%)$, serta yang mengeluarkan uang kisaran $>150,000$ berjumlah 1 responden $(1,1 \%)$.

\subsection{Uji Instrumen Penelitian}

1. Uji Validitas

Uji validitas yaitu mengkorelasikan masing-masing pernyataan dengan jumlah skor untuk masing-masing variabel. Syarat minimum untuk memenuhi syarat validitas adalah apabila nilai $\mathrm{r}_{\text {hitung }}>\mathrm{r}_{\text {tabel, }}$, berdasarkan perhitungan di tentukan bahwa nilai $r_{\text {tabel }}$ sebesar 0,1726. ${ }^{39}$

Melihat butir pertanyaan atau pernyataan yang valid adalah dengan melihat tabel Item Total Statistics, kemudian lihat pada kolom Corrected Item-Total Corelation.

Tabel 6

Hasil Uji Veliditas Instrumen

\begin{tabular}{|c|c|c|c|c|}
\hline \multicolumn{5}{|c|}{ Item-Total Statistics } \\
\hline & $\begin{array}{l}\text { Scale } \\
\text { Mean if } \\
\text { Item } \\
\text { Deleted }\end{array}$ & $\begin{array}{c}\text { Scale } \\
\text { Variance if } \\
\text { Item } \\
\text { Deleted }\end{array}$ & $\begin{array}{l}\text { Corrected } \\
\text { Item-Total } \\
\text { Correlation }\end{array}$ & $\begin{array}{l}\text { Cronbach's } \\
\text { Alpha if } \\
\text { Item Deleted }\end{array}$ \\
\hline $\mathrm{X} 1$ & 115.47 & 199.504 & .683 & .737 \\
\hline $\mathrm{X} 2$ & 115.37 & 198.126 & .731 & .735 \\
\hline $\mathrm{x} 3$ & 115.96 & 203.229 & 348 & .744 \\
\hline $\mathrm{X} 4$ & 115.61 & 196.812 & .653 & .734 \\
\hline $\mathrm{X} 5$ & 115.60 & 202.353 & .400 & .743 \\
\hline $\mathrm{X} 6$ & 116.00 & 197.143 & .546 & .736 \\
\hline $\mathrm{X} 7$ & 116.15 & 203.713 & .312 & .745 \\
\hline $\mathrm{x} 8$ & 115.43 & 199.062 & .665 & .737 \\
\hline $\mathrm{xg}$ & 115.35 & 199.526 & .737 & .737 \\
\hline $\mathrm{X} 10$ & 115.49 & 198.077 & .608 & .736 \\
\hline $\mathrm{X} 11$ & 115.23 & 200.134 & .735 & .738 \\
\hline $\mathrm{X} 12$ & 115.80 & 201.302 & .431 & .741 \\
\hline $\mathrm{X} 13$ & 115.09 & 203.882 & .454 & .744 \\
\hline $\mathrm{X} 14$ & 115.11 & 200.999 & .496 & .740 \\
\hline $\mathrm{X} 15$ & 115.63 & 196.038 & .662 & .733 \\
\hline $\mathrm{X} 16$ & 115.36 & 201.441 & .562 & .740 \\
\hline $\mathrm{X} 17$ & 115.27 & 198.947 & .739 & .736 \\
\hline $\mathrm{X} 18$ & 115.43 & 197.655 & .706 & .735 \\
\hline $\mathrm{X} 19$ & 115.32 & 201.207 & .604 & .740 \\
\hline $\begin{array}{l}\text { Total } \\
\mathrm{X}\end{array}$ & 59.32 & 52.658 & 1.000 & .899 \\
\hline
\end{tabular}

${ }^{39}$ Sugiyono, Metode, 20.

e-ISSN: 2686-6633 
Jurnal Ilmu Ekonomi dan Bisnis Islam - JIEBI

Vol.1 No. 1 Tahun 2019

\begin{tabular}{|l|r|r|r|r|}
\hline \multicolumn{7}{|c|}{ Item-Total Statistics } \\
\hline & $\begin{array}{c}\text { Scale } \\
\text { Mean if } \\
\text { Item } \\
\text { Deleted }\end{array}$ & $\begin{array}{c}\text { Scale } \\
\text { Variance } \\
\text { if Item } \\
\text { Deleted }\end{array}$ & $\begin{array}{c}\text { Corrected } \\
\text { Item-Total } \\
\text { Correlation }\end{array}$ & $\begin{array}{c}\text { Cronbach's } \\
\text { Alpha if } \\
\text { Item } \\
\text { Deleted }\end{array}$ \\
\hline Y1 & 40.86 & 49.529 & .644 & .742 \\
Y2 & 41.04 & 50.723 & .474 & .752 \\
\hline Y3 & 40.73 & 47.914 & .749 & .730 \\
\hline Y4 & 41.76 & 51.525 & .444 & .756 \\
\hline Y5 & 41.11 & 48.625 & .675 & .736 \\
Y6 & 41.41 & 48.333 & .603 & .737 \\
\hline Y7 & 40.73 & 48.552 & .697 & .735 \\
Y8 & 41.38 & 48.700 & .633 & .738 \\
\hline Totaly & 21.93 & 13.930 & 1.000 & .825 \\
\hline
\end{tabular}

Tabel di atas terlihat bahwa nilai rhitung pada kolom Corrected Item Total Correlation untuk masing-masing dari 2 variabel di atas dinyatakan valid karena $r_{\text {hitung }}>r_{\text {tabel }}(0,1726)$.

\section{Uji Reliabilitas}

Melakukan pengujian reliabilitas dalam penelitian ini digunakan program SPSS (Statistical Packaged For Sosial Siences) versi 16.0 dimana dalam mengukur reliabilitas disini menggunakan uji statistik Cronbach's Alpha (a). Suatu instrument dinyatakan reliabel jika memiliki Cronbach's Alpha (a) lebih dari 0,60.

Hasil pengujian reliabilitas instrument menggunakan alat bantu oleh statistik SPSS versi 16.0 dapat diketahui hasilnya sebagaimana tabel berikut.
Tabel 7

Hasil Uji Reliabilitas Instrumen

\begin{tabular}{|c|c|c|}
\hline & \multicolumn{2}{|c|}{ Reliability Statistics } \\
\hline Variabel & $\begin{array}{c}\text { Cronbach's } \\
\text { Alpha }\end{array}$ & $\mathrm{N}$ of Items \\
\hline Penggunaan Media Sosial (X) & .899 & 19 \\
\hline \multicolumn{3}{|c|}{ Reliability Statistics } \\
\hline Variabel & $\begin{array}{c}\text { Cronbach's } \\
\text { Alpha }\end{array}$ & $\mathrm{N}$ of Items \\
\hline Keputusan Pembbelian $(\mathrm{Y})$ & .825 & 8 \\
\hline
\end{tabular}

Pada tabel di atas dapat dilihat bahwa masing-masing variabel memiliki Cronbach's Alpha (a) lebih dari 0,60 (a> $0,60)$, variabel independen (Penggunaan Media Soaial) (X) dengan nilai Cronbach's Alphasebesar 0,899 dan variabel dependen (keputusan pembelian) (Y) dengan nilai Cronbach's Alphasebesar 0,825 yang artinya bahwa variabel $\mathrm{X}$ dan $\mathrm{Y}$ dinyatakan reliabel. Dengan demikian pengolahan data dapat dilanjutkan ke jenjang selanjutnya.

\section{Analisis Regresi Linear Sederhana}

Berdasarkan hasil olah data menggunakan SPSS 16.0 diperoleh hasil analisis regresi sederhana adalah sebagai berikut :

\begin{tabular}{|c|c|c|c|c|c|c|}
\hline \multicolumn{7}{|c|}{ Tabel 8} \\
\hline \multicolumn{7}{|c|}{ ANOVA } \\
\hline \multicolumn{2}{|c|}{ Model } & \begin{tabular}{l|} 
Sum of \\
Squares
\end{tabular} & Df & $\begin{array}{c}\text { Mean } \\
\text { Square }\end{array}$ & $\mathrm{F}$ & Sig. \\
\hline 1 & Regression & 457.041 & 1 & 457.041 & 50.747 & $.000^{2}$ \\
\hline & Residual & 810.567 & $90^{\circ}$ & 9.006 & & \\
\hline & Total & 1267.609 & 91 & & & \\
\hline & $\begin{array}{l}\text { tictors: (Con } \\
\text { endent Vani }\end{array}$ & $\begin{array}{l}\text { tant), Penge } \\
\text { tle: Keputu }\end{array}$ & $\begin{array}{l}\text { naanMe } \\
\text { in Pembel }\end{array}$ & $\begin{array}{l}\text { lia Sosial } \\
\text { ian }\end{array}$ & & \\
\hline
\end{tabular}

Dari hasil output di atas diketahui bahwa nilai $\mathrm{F}$ hitung $=50.747$ dengan tingkat signifikansi sebesar 0,000 < 0,05, maka model regresi dapat dipakai untuk memprediksi variabel Penggunaan Media Sosial atau dengan kata lain ada pengaruh variabel Penggunaan Media Sosial (X) terhadap Keputusan Pembelian (Y). 


\section{Uji T}

Uji T bertujuan untuk mengetahui besarnya Pengaruh Penggunaan Media Sosial terhadap Keputusan Pembelian Kuota Internet Pada Mahasiswa Fakultas Ekonomi dan Bisnis Islam IAIN Palu.

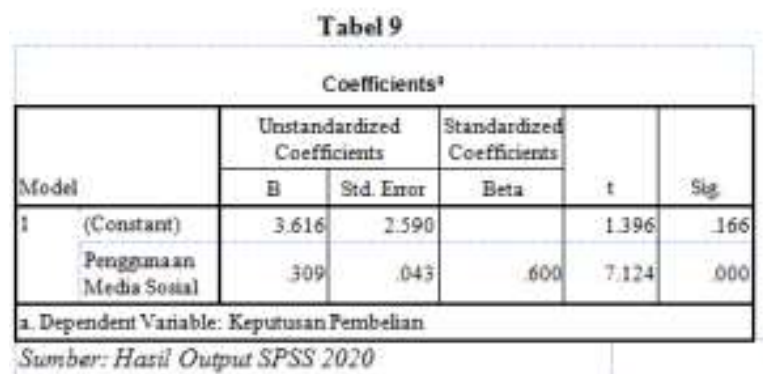

Berdasarkan Tabel Penggunaan Media Sosial $(X)$ diperoleh nilai $T_{\text {hitung }}$ $7.124>\mathrm{T}_{\text {tabel }} 1,661$ dan memiliki nilai signifikan (sig) 0.000 pada tabel coefficients dengan nilai a (tingkat signifikan) 0,05. Artinya $0.000<0,05$, dengan nilai ini memberikan makna bahwa variabel Penggunaan Media Sosial (X) memberikan pengaruh secara signifikan terhadap Keputusan Pembelian (Y).

Tabel 10

\begin{tabular}{|l|c|r|r|c|}
\hline \multicolumn{5}{|c|}{ Model Summary } \\
\hline Model & \multicolumn{1}{|c|}{$\mathrm{R}$} & R Square & $\begin{array}{c}\text { Adjusted R } \\
\text { Square }\end{array}$ & $\begin{array}{c}\text { Std. Error of the } \\
\text { Estimate }\end{array}$ \\
\hline 1 & $.600^{3}$ & .361 & .353 & 3.001 \\
\hline $\begin{array}{l}\text { a. Predictors: (Constant), Penggunaan Media Sosial } \\
\text { b. Dependent Variable: Keputusan Pembelian }\end{array}$ \\
\hline
\end{tabular}

Sumber: Hasil Output SPSS 2020

Tabel di atas menjelaskan besarnya nilai korelasi/hubungan (R) yaitu sebesar 0,600. Dari output tersebut diperoleh koefisien determinasi ( $R$ Square) sebesar 0,361 yang mengandung pengertian bahwa pengaruh variabel bebas (Penggunaan Media Sosial) terhadap variabel terikat (Keputusan Pembelian) adalah sebesar 36,1\% .

\subsection{Hasil Pengujian Hipotesis}

Uji hipotesis dilakukan dengan uji T. Uji T dilakukan untuk mengetahui Pengaruh Penggunaan Media Sosial terhadap Keputusan Pembelian Kuota Internet pada Mahasiswa Fakultas Ekonomi dan Bisnis Islam IAIN Palu.

Berdasarkan hasil perhitungan statistik pada tabel ... di atas, maka dapat diketahui bahwa variabel Penggunaan Media Sosial memiliki $\mathrm{T}_{\text {hitung }} 7.124>\mathrm{T}_{\text {tabel }} 1,661$, serta tingkat signifikansinya lebih kecil dari nilai alpha (a) yaitu 0,05. Artinya 0,000<0,05. Dengan demikian nilai ini menunjukkan bahwa variabel Penggunaan Media Sosial $(X)$ memberikan pengaruh yang signifikan terhadap variabel Keputusan Pembelian (Y). Berdasarkan uji $\mathrm{T}$ tersebut, hipotesis dalam penelitian ini menyatakan bahwa "Diduga bahwa penggunaan media sosial berpengaruh terhadap keputusan pembelian kuota internet pada mahasiswa Fakultas Ekonomi dan Bisnis Islam IAIN Palu." diterima.

\subsection{Pembahasan}

Hasil pengujian dengan menggunakan analisis regresi sederhana dengan bantuan SPSS 16.0, Pengaruh Penggunaan Media Sosial terhadap Keputusan Pembelian Kuota Internet pada Mahasiswa Fakultas Ekonomi dan Bisnis Islam, mempunyai pengaruh yang signifikan terhadap Keputusan Pembelian Kuota Internet pada Mahasiswa Fakultas Ekonomi dan Bisnis Islam IAIN Palu.

Pengaruh Penggunaan Media Sosial terhadap Keputusan Pembelian 
dapat dilihat dari hasil uji statistik diperoleh nilai $\mathrm{T}_{\text {hitung }} 7.124>\mathrm{T}_{\text {tabel }} 1,661$ dan memilki nilai signifikan (sig) 0,000 pada tabel coefficients dengan nilai a (tingkat siginfikan) 0,05. Artinya 0,000 < 0,05 . Dengan nilai ini memberikan makna bahwa variabel Penggunaan Media Sosial $(X)$ memberikan pengaruh secara siginfikan terhadap Keputusan Pembelian (Y). Adapun besaran pengaruh variabel $X$ terhadap variabel $Y$ yaitu sebesar 0,361 atau jika dipersentasekan yaitu 36,1\%. Hasil ini dapat memberikan gambaran bahwa responden (mahasiswa) memandang bahwa pengaruh penggunaan media sosial mampu mempengaruhi secara signifikan keputusan mahasiswa untuk membeli kuota internet.

Sesuai dengan hasil jawaban responden yang ada bahwa, 64 responden atau 58,7\% yang sangat setuju dengan pernyataan bahwa dengan kuota internet mereka bisa mencari informasi lewat media sosial. Hal ini dapat menjadi dorongan bagi para mahasiswa untuk melakukan Keputusan Pembelian kuota internet.

Berdasarkan hasil analisis dari jawaban responden tersebut, penggunaan media sosial menjadi salah satu alasan mahasiswa untuk melakukan keputusan pembelian kuota internet. Karena teknologi yang semakin maju dan tuntunan zaman serta kemudahan mengakses informasi lewat media sosial, maka membuat semakin tinggi minat masyarakat menggunakan kuota internet dengan begitu dapat meningkatkan Keputusan Pembelian pada mahasiswa Fakultas Ekonomi dan Bisnis IslamIAIN Palu.

Hasil penelitian sejalan dengan penelitian yang dilakukan oleh Mila
Setiawati, yang menunjukkan bahwa media sosial sangat berpengaruh terhadap minat beli konsumen pada Mahasiswa program studi Manajemen Universitas Pasir Pengaraian. ${ }^{40}$

Kebutuhan akan informasi sekarang ini menjadi kebutuhan yang sangat penting untuk dipenuhi. Keputusan masyarakat dalam menggunakan kuota internet tidak terlepas dari penggunaaan media sosial yang mereka inginkan untuk mendapatkan informasi. Tuntunan zaman kemudian akan menjadikan seseorang berubah menjadi lebih konsumtif.

Sebagai seorang muslim hendak memperhatikan prinsip ekonomi yang disyariatkan Islam adalah agar tidak bermewah-mewah, memenuhi apa yang kita inginkan sesuai dengan kebutuhan bukan dengan sesuai keinginan, menjauhi israf dan tabzir.

Israf menurut Afzalur Rahman merupakan pengeluaran yang berlebihlebihan pada hal-hal yang dihalalkan tanpa peduli apakah itu sesuai dengan kemampuan atau tidak, dan pengeluaran dengan alasasn kedermawanan hanya sekedar pamer belaka. Sedangkan Tabzir adalah membelanjakan atau mengeluarakan uang atau harta benda yang tidak memiliki manfaat dan bukan dijalan Allah. ${ }^{41}$

${ }^{40}$ Mila Setiawati, Pengaruh Media Sosial TerhadapMinat Beli Konsumen (Studi Kasus Mahasiswa Manajemen Universitas Pasir Pengaraian, Universitas Pasir Pengaraian,2015.

${ }^{41}$ Rozalinda, Ekonomi Islam Teori dan Aplikasinya pada Aktivitas Ekonomi, (Cet. 3, Jakarta, PT. Raja Grafindo Persada, 2006), 109. 
Konsumen Muslim juga harus menahan diri dari konsumsi yang berlebihan. Sebagaimana dalam Q.S AlA'raf ayat 31 Allah SWT berfirman yang terjemahannya:

"Hai anak Adam, pakailah pakaianmu yang indah di setiap (memasuki) mesjid, makan dan minumlah, dan janganlah berlebihlebihan. Sesungguhnya Allah tidak menyukai orang-orang yang berlebih-lebihan." 42

Maksud dari kalimat "..makan dan minumlah, dan janganlah berlebih-lebihan.," adalah dalam setiap melakuan konsumsi, konsumen muslim haruslah jangan melampaui batas yang dibutuhkan dan jangan pula melampaui batas-batas makanan yang dihalalkan. ${ }^{43}$

Dalam Islam, konsumsi tidak dapat dipisahkan dari peranan keimanan, hal ini menjadi tolak ukur penting karena keimanan memberikan cara pandang yang cenderung mempengaruhi perilaku dan kepribadian manusia. Keimanan sangat mempengaruhi kuantitas dan kualitas konsumsi baik dalam bentuk kepuasan material maupun spiritual, yang kemudian membentuk kecenderungan.

Menurut Imam al-Ghazali, kebutuhan (hajat) adalah suatu yang dibutuhkan manusia dalam rangka mempertahankan kelangsungan hidupnya dan menjalankan fungsinya yaitu menjalankan tugasnya sebagai

\footnotetext{
${ }^{42}$ Kementrian AgamaRepublik Indonesia, $\mathrm{Al}$ Qur'an dan Terjemahnya, (Jakarta PT. Al-Quran Terkemuka, 2010), 154.

${ }^{43}$ Mardani, Ayat-Ayat Dan Hadis Ekonomi Syariah, (Ed.1-Cet.1, Jakarta: Rajawali Pers, 2011), 92.
}

hamba Allah dengan beribadah secara maksimal. Al-Ghazali menekankan pada nilai moral yang begitu ketat dalam memasukkan "keinginan" (wants) dalam motif aktivitas ekonomi terutama dalam konsumsi. Kebutuhan" (needs) menjadi nafas dalam perekonomian bernilai moral Islam ini, bukan keinginan. Kebutuhan (al-hajah/need) lebih didefinisikan sebagai segala keperluan dasar manusia untuk kehidupannya. Sementara keinginan (alRaghbah wa al-Shahwah/wants) didefini-sikan sebagai desire (kemauan) manusia atas segala hal. Jadi ruang lingkup definisi keinginan akan lebih luas dari definisi kebutuhan. Hingga saat ini, umumnya orang berpendapat bahwa kebutuhan manusia terbagi menjadi dalam tiga hal yaitu kebutuhan primer, sekunder dan tersier. Demikian juga Al-Ghazali juga membagi kebutuhan manusia menjadi tiga bagian dilihat dari kekuatan subtansinya maslahah yaitu: Pertama, daruriyyah yaitu tujuan yang menempati posisi darurat (kebutuhan primer). Kedua, hajjiyah yaitu kebutuhan menempati posisi hajat (kebutuhan skunder). Ketiga, tahsiniyyat wa al-zinat (kebutuhan pelengkap penyempurna), yang berada di bawah hajat. ${ }^{44}$ Sehingga dalam hal ini islam harus lebih mengedepankan keinginan dibandingkan dengan kebutuhan. Dalam kasus ini keputusan pembelian kuota internet menjadi suatu kebutuhan mahasiswa di kampus IAIN palu karena akses internet dari WIFI masih belum

\footnotetext{
${ }^{44} \mathrm{Cucu}$ Komala, "Perilaku Konsumsi Impulsive Buying Perspektif Imam Al-Ghazali”, Jurnal Perspektif, Vol. 2 No. 2 Desember 2018, 254256.
} 
tersebar secara merata dan koneksinya yang buruk.

Islam tidak melarang manusia untuk memenuhi kebutuhan ataupun keinginannya karena semua yang ada di bumi ini diciptakan untuk kepentingan manusia. Namun, manusia diperintahkan untuk mengonsumsi barang/jasa yang halal dan baik saja secara wajar dan tidak berlebihan. Begitu juga dengan kesenangan dan kemewahan. Kesenangan atau kemewahan diperbolehkan asalkan tidak berlebihan, yaitu tidak melampaui batas yang sudah ditentukan.

\section{Kesimpulan}

Dari hasil pengolahan data dan analisis data dalam penelitian yang membahas tentang pengaruh penggunaan media sosial terhadap keputusan pembelian kuota internet pada mahasiswa fakultas ekonomi dan bisnis islam iain palu" dapat disimpulkan bahwa variabel penggunaan media sosial berpengaruh secara signifikan terhadap keputusan pembelian kuota internet yang dibuktikan dengan nilai $\mathrm{T}_{\text {hitung }} 7.124>$ $\mathrm{T}_{\text {tabel }}$ 1,661 dan memiliki nilai signifikan sebesar $0.000<0,05$, maka dapat disimpulkan bahwa $\mathrm{H}_{0}$ ditolah dan $\mathrm{H}_{1}$ diterima yang artinya bahwa variabel penggunaan media sosial berpengaruh signifikan terhadap keputusan pembelian.

Sebagai seorang muslim hendak memperhatikan prinsip ekonomi yang disyariatkan Islam agar tidak bermewah-mewah, memenuhi apa yang kita inginkan sesuai dengan kebutuhan bukan dengan sesuai keinginan, menjauhi israf dan tabzir. Dalam kasus ini keputusan pembelian kuota internet menjadi suatu kebutuhan mahasiswa di kampus IAIN palu karena akses internet dari WIFI masih belum tersebar secara merata dan koneksinya yang buruk.

\section{Daftar Pustaka}

Andreas, Kaplan M., Haenlein Michael 2010. "Users of the world, unite! The challenges and opportunities of social media". Business Horizons 53 (1).

Ardianto, Elvinaro, Komunikasi Massa Suatu Pengantar, Bandung: Simbiosa Rekatama Media, 2004.

Anang Sugeng Cahyono, 2016, "Pengaruh Media Sosial Terhadap Perubahan Sosial Masyarakat di Indonesia", Jurnal Penelitian.

Carlos, Jon Wora, Pengaruh Harga dan Kualitas Produk Terhadap Keputusan Pembelian Layanan Internet Indosat Ooredoo, Universitas Sanata Dharma Yogyakarta,2017.

Cindy, Aprillia Bunga, Analisis Pengaruh Harga Paket, Kualitas Jaringan dan Promosi Terhadap Keputusan Pembelian Kartu Perdana Internet pada Mahasiswa Fakultas Ekonomi dan Bisnis Universitas Muhammdiyah Surakarta, Universitas Muhammaduyah Surakarta.2017.

Damsar, Pengantar Sosiologi Pendidikan, Jakarta: Kencana, 2011.

Daryanto dan Ismanto setyabudi, Konsumen dan Pelayanan Prima, Yogyakarta: Gava media, 2014.

Depdiknas RI, Kamus Besar Bahasa Indonesia, Jakarta : Balai Pustaka, 2002.

Departemen Agama Republik Indonesia, Terjemah $\mathcal{E}$ Tafsir Al-Qur'an, Jakarta: Fa, Sumatra, 1978. 
Hamdi, Asep Saipul dan E Baharuddin, Metode Penelitian Kuantitatif Aplikasi dalam Pendidikan, Cet 1, Yogyakarta: Deepulish, 2014.

Indrawijaya, Sigit, "Pengaruh Kualitas Produk dan Word Of Mouth Terhadap Keputusan Konsumen Dalam Pembelian Roti Manis Pada Industri Kecil Di Kabupaten Sarolangun", Jurnal Ekonomi Vol.1, No.3, 2012.

Kaplan, Andreas, dan Michael Haenlein, "Users of the world, unite! The challenges and opportunities of Social Media", Business Horizons, 2010.

Khotler, Philip dan Kevin Lene keller, Manajemen Pemasaran, Edisi 12, Jilid I, Erlangga, 2008.

Khoter, Philip, Manajemen Pemasaran Prenhallindo, edisi 9, Jakarta, 2009.

Lembang, Rosvita Dua, Analisi Pengaruh Kualitas Produk, Harga, romosiI dan Cuaca Terhadap Keputusan Pembelian Teh Siap Minum Dalam Kemasan Teh Botol Sosro, Universitas Diponegoro, 2010.

Martono, Nanang, Sosiologi Perubahan Sosial: Perspektif Klasik, Modern, Posmodern dan Poskolonial, Jakarta: Rajagrafindo Persada, 2012.

McQuail, Denis, Teori Komunikasi Massa Suatu Pengantar, Jakarta: Erlangga, 1992.

Nasrullah, Rulli, Komunikasi Antarbudaya di Era Budaya Siber, Jakarta: Kencana Prenada Media Group, 2012.

Noor, Juliansyah, Metodologi Penelitian: Skripsi, Tesis, Disertasi, dan Karya Ilmiah, (Jakarta; Kencana, 2014).

Nurly Meilinda, SOCIAL MEDIA ON CAMPUS: Studi Peran Media Sosial sebagai Media Penyebaran Informasi Akademik pada Mahasiswa di Program
Studi Ilmu Komunikasi FISIP UNSRI, The Journal of Society \& Media, Vol 2 (1), 2018.

Nugroho, Setiadi J, Perilaku Konsumen, Jakarta: Prenada Media Group, 2010.

Nurdin, N. (2017). Research in Online Space: The Use of Social Media for Research Setting Jurnal Sistem Informasi (Journal of Information System), 13(1), 6777.

Nurdin, N., Novia, N., Rahman, A., \& Suhada, R. (2019). Potensi Industri Produk Makanan Halal Di Kota Palu. Jurnal Ilmu Ekonomi dan Bisnis Islam, 1(1), 1-12.

Nurdin, N., \& Rusli. (2012). Social Media Adoption and Use Within Indonesian Muslim Scholars: A Possible Adoption and Use for "Dakwah" Purposes Annual Conference on Islamic Studies (ACIS) 12 November 05-08 2012, Surabaya Indonesia.

Nurdin, N., \& Rusli. (2013). Spiritualising New Media: The Use of Social Media for Da'wah Purposes within Indonesian Muslim Scholars. Jurnal Komunikasi islam, 3(1), 1-21. http://jki.uinsby.ac.id/index.php /jki/article/view/55

Nurdin, N., Stockdale, R., \& Scheepers, H. (2013). The Use of Social Media to Gather Qualitative Data: A Case of Government EProcurement Implementation and Use. 24th Australasian Conference on Information Systems (ACIS) 
Peraturan Menteri Agama Republik Indonesia Nomor 27 Tahun 2018 Tentang Perubahan Kedua Atas Peraturan Menteri Agama Nomor 92 Tahun 2013 Tentang Organisasi Dan Tata Kerja Institut Agama Islam Negeri Palu

Priyanto, Dwi, Analisis Korelasi, Regresi dan Multivariate Dengan SPSS (Cet., 1; Yogyakarta: Gava Media, 2013.

Rahmani, Thea, Penggunaan Media Sosial Sebagai Penguasaan Dasar-Dasar Fotografi Ponsel, Universitas Islam Negeri Sunan Kalijaga Yogyakarta, 2016.

Rasyidah, Dyah Sari, Pengaruh Penggunaan Media Sosial Terhadap Intensitas Belajar Pendidikan Agama Islam Siswa Kelas VIII di SMP N 3 Karangdowo Klaten Tahun Ajaran 2016/2017, Institut Agama Islam Negeri Surakarta, 2017.

Riduwan, Belajar Mudah Penelitian Untuk Guru, Karyawan dan Peneliti Pemula, Bandung: Alfabeta,2005.

Rini, Agustina.S dan Riyanti.I, Ilmu Perilaku Konsumen, Malang: UB Press, 2012.

Rochaety, Ety, Metodologi Penelitian Bisnis: Dengan Aplikasi SPSS Edisi Pertama, Jakarta: Mitra Wacana Media, 2007.

Sarjono, Hariadi, dan Winda Julianti, SPSS vs LISREL: Sebuah Pengantar Aplikasi Untuk Riset, Jakarta: Salemba Empat, 2011.

Setiawati, Mila, Pengaruh Media Sosial TerhadapMinat Beli Konsumen (Studi Kasus Mahasiswa Manajemen Universitas Pasir Pengaraian, Universitas Pasir Pengaraian,2015.

Simamora, Bilson, Panduan Riset Perilaku Konsumen, Jakarta: PT Gramedia Pustaka Utama, 2000.
Siregar, Syofian, Metode Penelitian Kuantitatif, Jakarta: PT Fajar Interpratama, 2013.

Subagyo dan Djarwano, Statistika Induktif, Yogyakarta: BPFE Yogyakarta, 2005.

Sudarsono, Heri, Konsep Ekonomi Islam, (Yogyakarta: Ekonosia, 2002.

Sugeng, Anang Cahyono, "Pengaruh Media Sosial Terhadap Perubahan Sosial Masyarakat di Indonesia" Jurnal Ilmu Sosial dan Ilmu Politik. Vol.9 no.1, 2016.

Sugiyono, Metode Penelitian Kuantitatif Kualitatif dan RED, Bandung: Alfabeta,2011.

Sugiyono, Statistika Untuk Penelitian, Bandung: alfabeta, 2012.

Sumarein, Ekonomi Islam, Yogyakarta: Graha Ilmu, 2013.

Surat Keputusan Menteri Agama Republik Indonesia Nomor 100/In.13/Kp.07.6/02/2019

Tentang Pengangkatan Dekan Institut Agama Islam Negeri Palu

Suryani dan Hendrayani, Metode Riset

Kuantitatif Teori dan Aplikasi pada

Penelitian Bidang Manajemen dan Ekonomi Islam, (Jakarta: Prenada Media Group, 2015),

Tim Pusat Humas Kementerian Perdagangan RI, 2014, Panduan Optimalisasi Media Sosial Untuk Kementrian Perdagangan RI.

Walker, Boyd, Manajemen Pemasaran, Jilid I, Jakarta: Erlangga, 1997.

Qardhawi, Yusuf, Norma dan Etika Ekonomi Islam, Jakarta: Gema Insani Press, 1997.

Agus Tri Haryanto, "130 Juta Orang Indonesia Tercatat Aktif di Medsos", https://inet.detik.com/cyberlife/d -3912429/130-juta-orangindonesia-tercatat-aktif-di-medsos, 
di akses pada tanggal 26 Agustus 2019, pukul 14.26.

Fatimah Kartini Bohang, "Berapa Jumlah Pengguna Internet Indonesia?", diakses dari https://tekno.kompas.com/read/ 2018/02/22/16453177/berapajumlah-pengguna-internetindonesia, pada tanggal 1 Juli 2019 pada pukul 20.30.

Katadata.co.id, 2019, "Berapa Pengguna Media Sosial Indonesia?", https://databoks.katadata.co.id/d atapublish/2019/02/08/berapapengguna-media-sosial-indonesia, diakses pada tanggal 14 juli 2019 pukul 22.10.

KOMINFO, "Angka Penggunaan Media Sosial Orang Indonesia Tinggi, Potensi Konflik juga Amat Besar", https://www.kominfo.go.id/conte nt/detail/14136/angkapenggunaan-media-sosial-orangindonesia-tinggi-potensi-konflikjuga-amat-besar/0/sorotan_media, diakses tanggal 26 Agustus, pukul 11.14.

Nurdin, N. (2012). Penggunaan Media Sosial Online dalam Berdakwah: Kemungkinan Adopsi dan Strategi Pemanfaatannya. AlMishbah: Jurnal Ilmu Dakwah dan Komunikasi, 8(1), 177-198.

Nurdin, N. (2017a). Research in Online Space: The Use of Social Media for Research Setting Jurnal Sistem Informasi (Journal of Information System), 13(1), 67-77.

Nurdin, N. (2017b). To Research Online or Not to Research Online: Using Internet-Based Research in Islamic Studies Context.
Indonesian Journal of Islam and Muslim Societies, 7(1), 31-54.

Nurdin, N., \& Rusli. (2012). Social Media Adoption and Use Within Indonesian Muslim Scholars: A Possible Adoption and Use for "Dakwah" Purposes Annual Conference on Islamic Studies (ACIS) 12 November 05-08 2012, Surabaya Indonesia.

Nurdin, N., \& Rusli. (2013). Spiritualising New Media: The Use of Social Media for Da'wah Purposes within Indonesian Muslim Scholars. Jurnal Komunikasi islam, 3(1), 1-21. http://jki.uinsby.ac.id/index.php /jki/article/view/55

Nurly Meilinda, 2018, "SOCIAL MEDIA ON CAMPUS: Studi Peran Media Sosial sebagai Media Penyebaran Informasi Akademik pada Mahasiswa di Program Studi Ilmu Komunikasi FISIP UNSRI", The Journal of Society \& Media, Vol 2 (1).

Sahid Raharjo, "Uji Heteroskedastisitas dengan Rank Spearman dalam SPSS", https://www.konsistensi.com/201 7/01/uji-heteroskedastisitasdengan-rank.html, di akses pada tanggal 21 Mei 2020, pukul 12.11.

Wahyunanda Kusuma Pertiwi, "Riset Ungkap Pola Pemakaian Medsos Orang Indonesia", https://tekno.kompas.com/read/ 2018/03/01/10340027/risetungkap-pola-pemakaian-medsosorang-indonesia?page $=2$, diakses tanggal 26 Agustus 2019, pukul 10.47. 